\title{
Relevant Factors to Explain Cross-Section of Expected Returns of the Firms Listed in the Dhaka Stock Exchange
}

\author{
Shah Saeed Hassan Chowdhury ${ }^{1} \&$ Rashida Sharmin ${ }^{1}$ \\ ${ }^{1}$ Department of Accounting and Finance, Prince Mohammad Bin Fahd University, Al Khobar, Saudi Arabia \\ Correspondence: Shah Saeed Hassan Chowdhury, Department of Accounting and Finance, Prince Mohammad Bin \\ Fahd University, Al Khobar, Saudi Arabia. Tel: 966-3-849-9332. E-mail: schowdhury@pmu.edu.sa
}

Received: December 21, 2012

Accepted: January 21, $2013 \quad$ Online Published: January 31, 2013

doi:10.5539/ibr.v6n3p165

URL: http://dx.doi.org/10.5539/ibr.v6n3p165

\begin{abstract}
Using the well-known Fama-MacBeth methodology, this paper investigates the factors that may influence the cross-section of stock returns in the Dhaka Stock Exchange (DSE). Various combinations of factors such as dividend yield, size, price-earnings ratio, market return, spread between large and small firms, lagged values of factors, illiquidity of stocks, and cross-sectional volatility of the market are considered. However, results show that these factors hardly explain the cross-section of stock returns. Only market returns weakly explain stock returns. Interestingly, the relationship between market returns and stock returns has been consistently found to be negative, which contradicts the established notion of positive risk-return relationship. Even after considering for the effects of size, liquidity, and sub-periods, results do not change much.
\end{abstract}

Keywords: cross-section, CAPM, Dhaka Stock Exchange, illiquidity, frontier stock markets, emerging markets

\section{Introduction}

Sharpe (1964), Lintner (1965), and Mossin (1966) develop Capital Asset Pricing Model (CAPM), which is considered as the foundation of modern finance theory. The single-period CAPM shows linear relationship between the expected return and market risk of a security. Thus, no factors besides market risk, which is expressed by the slope coefficient (beta), should be able to explain security returns. However, many research papers in the late 1970's and throughout 1980's have shown that factors other than market return are capable of explaining stock's returns. Lintzenberger and Ramaswamy (1979) find a significant positive relationship between dividend yield and common stock return. Banz (1981) and Reinganum (1981) show that common stocks of small firms produce higher risk-adjusted returns than that of large firms. Lakonishok and Shapiro (1984) report that the difference of returns between the smallest and largest companies is about 1.2 per cent per month. Thus, CAPM faces a serious challenge to survive as an effective asset pricing model.

In an influential paper, Fama and French (1992a) show that when portfolios are formed on size alone, there seems to be evidence that average return is positively related to beta. The betas of size portfolios are highly correlated with size, which makes the size portfolios unable to distinguish between beta and size effects in average returns. Thus, when they divide the size portfolios on the basis of pre-ranking betas, they find a strong relation between average return and size, but relation between return and beta disappears. Later Fama and French (1993) show that size and book-to-market equity are important proxy for common risk factors to explain stock returns.

Researchers document a negative relationship between the expected returns and liquidity for the U.S. stocks [e.g., Amihud \& Mendelson, 1986; Brennan et al., 1998; Chordia et al., 2001]. These findings suggest that infrequently traded stocks provide higher returns to the investors. This extra return (that is, liquidity risk premium) occurs because infrequently traded stocks might be riskier than frequently traded stocks as investors of the former cannot quickly adjust their portfolios in response to market changes. Chordia (2000), Liu (2006), and Pastor and Stambaugh (2001) also report that the stock liquidity plays an important role in the pricing of financial assets.

Some papers argue that investor psychology is the reason for return anomalies. Some return anomalies are attributed to momentum effects, which is first documented in Jegadeesh and Titman (1993). In a seminal paper, they show that buying past winners and selling past losers lead to substantial abnormal returns. Daniel et al. (1998) suggest that overconfidence induces overreaction, which ultimately causes stock prices to go away from fundamental value. Grinblatt and Han (2005) point that loss aversion can help explain momentum phenomenon 
because past winners have more selling pressure than past losers. Chordiaet al. (2012) find that many of the previously well-known predictors cannot predict stock return in recent times, mainly because technological development enables investors to handle large volume of stocks at much reduced trading costs.

Fama and French (2008) show that regardless of the size group, accruals, net stock issues, and momentum are other main sources of asset price anomalies. Cakici et al. (2012) use very recent data and find strong evidence of value and momentum effects in 18 emerging stock markets. Moreover, they find that local factors explain cross-section of emerging market returns, suggesting that emerging markets are segmented from the developed ones.

All of these findings boil down to one thing - CAPM beta is not enough to explain stock returns and we have to find alternative models, which contain better predictors. A multi-factor model could be a solution. However, emerging markets are different from developed markets, which create several problems for the academicians. First, there is less published research on emerging markets, which means that possibly many peculiarities of such markets are still unknown. Bangladesh, an emerging market (or, strictly speaking, a frontier market), indeed is a less known market due to the same reason. Second, many of the standard finance theories are not applicable in emerging markets due to the idiosyncratic features such as weak regulatory authority, nonsynchronous trading, low liquidity, etc. Third, research on emerging markets is not so easy due to unavailability of reliable data. This is especially true for research on microstructure issues of these markets. Thus, we only know partially about the microstructure characteristics of these markets.

Using well-known Fama and MacBeth (1973) methodology, this paper examines factors such as market return, size, $\mathrm{P} / \mathrm{E}$ ratio, dividend yield, size premium, illiquidity of stocks, lagged value of factors, and cross-sectional volatility to find which ones may explain the cross-section of returns of Bangladeshi stocks. There are only few studies on the use of factor models to explain cross-section of Bangladesh stock returns. In a previous study, Chowdhury et al. (2003) show that contrary to the findings in the developed markets, additional factors like size, market-to-book equity, and price-earnings ratio cannot explain the cross-section of stock returns in the DSE. However, unlike us, they do not consider firm attributes such as liquidity and size in sorting firms to construct portfolios. In a somewhat similar study, Ali (2011) finds that inflation has negative influence on stock returns and industrial production index, market $\mathrm{P} / \mathrm{Es}$ and monthly percent average growth in market capitalization have positive influence on DSE stock returns. However, his technique uses index data rather than firm level data. Thus, our study is likely to contribute significantly to the extant literature on Bangladesh stock market.

Rest of the paper is organized as follows. Section 2 provides literature review of the relevant studies, with more emphasis on recent ones. Section 3 discusses how data are collected and specification of the models used in the study. Section 4 analyzes the empirical results. Section 5 gives concluding remarks on the overall findings of the study.

\section{Cross-Section of Returns and Relevant Factors: Empirical Evidence}

Brown et al. (1983) find that size effect is linear in the logarithm of size, but rejects the hypothesis that this effect is stable through time. That is, due to the instability of effect, estimates are sensitive of time period studied. Lo and Mackinlay (1990) document that returns to portfolios of small company stocks tend to lag returns to portfolio of large company stocks. On the other hand, lagged returns on small company stocks are not correlated with contemporaneous returns on large company stocks.

Fama and French (1992b) have shown that size and book-to-market are proxy for common risk factors in returns. They further show how size and book-to-market equity are related to economic fundamentals. Fama and French (1993) use three factors - an overall market, firm size, and book-to-market equity - to explain stock market returns. They find the evidence that size and book-to-market equity are indeed proxy for sensitivity to common risk factors in stock returns.

Zhang (2006) argues that stocks with greater information uncertainty are more prone to mispricing. Hou and Robinson (2006) show that firms in non-concentrated industries earn higher expected returns than firms in concentrated industries. Their argument is that the concentrated industries have higher barriers to entry, resulting in lower non-diversifiable risk. Fang and Peress (2009) document the presence of premium for 'neglected stocks' by giving the evidence that stocks with low media coverage earn higher expected returns than stocks with high coverage. Avramov and Chordia (2006) use size, book/market, and default spread as factor loadings to find the ability of firms to survive during the time of economy-wide turbulence. Their findings indicate that conditional analysis reduces the strength of size and book/market as the predictors of stock returns.

Rouwenhorst (1999) investigates 20 emerging markets and finds no relation between turnover and cross-sectional 
returns but finds a positive relationship between turnover and beta, size, and momentum. Dey (2005) finds that, as far as the emerging markets are concerned, there exists a positive relationship between turnover and stock returns. Sang-Gyung et al. (2003) report that active management of an index may lead to higher liquidity and value. Obiedat (2009) finds a significant effect of earnings per share and book-to-market value on stock price in the Abu Dhabi stock market, whereas no significant effect of dividend per share was found.

Only few studies have so far made an effort to address the appropriate factors that explain the cross-section of returns in the Bangladesh stock market. Here we discuss the findings of the studies that tried to find factors to explain stock returns in the DSE or address the anomalies of stock return. Sadique and Chowdhury (2001) fail to obtain any prospect of lagged price and volume to predict the current and future price changes. However, they find that past trading volume and price changes can predict present and future changes in trading volume. Sadique and Chowdhury (2002) have found significant positive serial dependence in the weekly returns of the DSE over the short run. A study by Chowdhury et al. (2001) finds that beta simply fails to explain the cross-section of DSE-listed stocks. Mobarek and Mollah (2005) show that size, price to book, volume of shares traded, earnings yield and cash flow yield explain returns of the stocks listed in the DSE. Islam et al. (2006) show that although cross sectional returns are explained little by companies' size and the market-to-book value ratio individually, but in aggregate these two factors play an important role. Their results also show the importance of time variation on the volatility of stock prices of the Bangladesh stock market. Uddin et al. (2007) use 73 DSE stocks to examine liquidity risk and report the presence of liquidity premium in the market.

\section{Data and Methodology}

This paper uses monthly stock price data of all the companies listed in the Dhaka Stock Exchange. Monthly return series is calculated as the logged difference of stock prices on the last trading days of two consecutive months times 100 . Stock price, market capitalization, price-earnings ratio, and dividend yield data are collected from Thomson Datastream. Natural log of individual stock's market capitalization is the proxy for firm size. We create the SMB (Small Minus Big) series by taking the difference between the average return of the smallest one-third companies and that of the largest one-third companies listed in the DSE. Beta is estimated every month based on the returns of the stock and that of the market in the past 24 months. We use market model to estimate beta for individual firms. In the same manner, we estimate the coefficients of every factor to find the sensitivity of returns of the individual stock to that particular factor.

Thus, the sensitivities of a portfolio $i$ to the risk factors at time $t$ are denoted by $\beta_{i, t}^{m}, \beta_{i, t}^{s m b}, \beta_{i, t}^{p e}, \beta_{i, t}^{m v}$, and $\beta_{i, t}^{d y}$. Our approach is based on the Fama-MacBeth (1973) two-stage methodology, which is widely used in empirical asset pricing. We estimate the Fama-French betas for every firm from the following time-series regression,

$$
r_{i, t}=\alpha_{i, t}+\beta_{i, t}^{m} r_{m, t}+\beta_{i, t}^{s m b} r_{s m b, t}+\beta_{i, t}^{p e}(P E)_{i, t}+\beta_{i, t}^{m v}(M V)_{i, t}+\beta_{i, t}^{d y}(D Y)_{i, t}+\epsilon_{i, t}
$$

where $r_{i, t}, r_{m, t}, r_{s m b, t},(P E)_{i, t},(M V)_{i, t}$, and $(D Y)_{i, t}$ represent return of asset $i$, market return, return on the $\mathrm{SMB}$, price-earnings ratio of firm $i$, size (market capitalization) of firm $i$ and dividend yield of firm $i$, respectively. This procedure is repeated by rolling the window of 24 months of observations one month ahead. Rolling windows of 24 months make an appropriate compromise between adjusting to the latest changes and avoiding of noise in the monthly estimations. Although rolling five-year windows have also been suggested in earlier literature such as Groenewold and Fraser (1997) and Fraser et al. (2004), we have used 24 months mainly due to our data set of shorter time span. Next, we estimate the coefficients $\lambda_{0, t}, \lambda_{m, t}, \lambda_{s m b, t}, \lambda_{p e, t}, \lambda_{m v, t}$, and $\lambda_{d y, t}$, using the estimated betas $\beta_{i, t}^{m}, \beta_{i, t}^{s m b}, \beta_{i, t}^{p e}, \beta_{i, t}^{m v}$, and $\beta_{i, t}^{d y}$ from equation 1, i.e. estimating cross-sectional regressions for every month,

$$
r_{i, t}=\lambda_{0, t}+\lambda_{m, t} \beta_{i, t}^{m}+\lambda_{s m b, t} \beta_{i, t}^{s m b}+\lambda_{p e, t} \beta_{i, t}^{p e}+\lambda_{m v, t} \beta_{i, t}^{m v}+\lambda_{d y, t} \beta_{i, t}^{d y}+\xi_{i, t}
$$

Where $\lambda_{j, t}$ 's, $j=0, m, s m b, p e, m v$, and $d y$, are the risk premia which offset the investors for taking one unit of risk from corresponding risk factor. The coefficient $\lambda_{0, \mathrm{t}}$ is interpreted as the expected return of a zero beta portfolio.

Due to the findings in the previous literature that liquidity is important factor to explain stock returns, we have also sorted firms based on illiquidity (Note 1). It is difficult to measure liquidity of the individual stocks as well as the market. Researchers have used various measures of liquidity. Brennan and Subrahmanyam (1996) measure stock liquidity by price response to order size and the fixed cost of trading. Easley et al. (1999) use the probability of information-based trading estimated from intra-daily transaction data as a proxy for microstructure risk. Amihud and Mendelson (1986) and Eleswarapu (1997) use bid-ask spread as a measure of liquidity. All these are fine measures of illiquidity that requires data of transactions and quotes that are unavailable in emerging stocks markets such as Bangladesh. Thus, we use the illiquidity measure given by Amihud (2002). His measure of illiquidity 
needs only data on returns and volume which are available for most markets for reasonable period. Amihud (2002) defines liquidity as

$$
I L L_{d}^{i}=\frac{a b s\left(R_{d}^{i}\right)}{V A L_{d}^{i}}
$$

Where $R_{d}^{i}$ is the return for stock $i$ on day $d . V A L_{d}^{i}$ is the trading value for stock $i$ on day $d$ in millions of taka (local currency), and $I L L_{d}^{i}$ represents the absolute percentage price change per million taka of trading value. Amihud points out that this measure has the intuitive interpretation of measuring average association between a unit of volume and the price change that other liquidity ratios do not have. Monthly illiquidity can be estimated as

$$
I L L_{m}^{i}=1 / D_{i m} \sum_{d=1}^{D_{i m}} \frac{a b s\left(R_{m d}^{i}\right)}{V A L_{m d}^{i}}
$$

Thus, monthly market illiquidity is the average of illiquidity across stocks in market in the month $m$. (Note 2)

\section{Analyses of Results}

Table 1 shows the results obtained from the basic model given in equation (2). Various combinations of factors (given by model numbers) are also used to find the relevant factors that potentially explain the cross-section of returns of the DSE firms. There are six different models in the table, hence six combinations. Four observations on Table 1 are noteworthy. First, in every model, constant is always significantly positive. Second, market return seems to have significantly inverse relationship with cross-sectional returns, which contradicts with the notion that risk and return are positively related. Using intertemporal CAPM Merton (1973) suggests a positive relation between risk and return. Fama and Schewrt (1977), Breen et al. (1989), and Glosten et al. (1993) provide empirical evidence of time variation in the relation between risk and return.

\begin{tabular}{|c|c|c|c|c|c|c|}
\hline Model & Constant & $\lambda_{m}$ & $\lambda_{p e}$ & $\lambda_{d y}$ & $\lambda_{m v}$ & $\lambda_{s m b}$ \\
\hline \multirow[t]{2}{*}{ Model 1} & 1.42 & -0.6281 & 0.0038 & -0.0008 & 0.0000 & -0.5745 \\
\hline & $(3.51)^{*}$ & $(-2.61)^{*}$ & $(-1.22)$ & $(-0.19)$ & $(-0.15)$ & $(-2.10)^{*}$ \\
\hline \multirow[t]{2}{*}{ Model 2} & 1.4318 & -0.5903 & -0.0025 & -0.0014 & 0.0000 & \\
\hline & $(3.34)^{*}$ & $(-2.56)^{*}$ & $(-0.87)$ & $(-0.32)$ & $(-0.07)$ & \\
\hline \multirow[t]{2}{*}{ Model 3} & 1.3685 & -0.5098 & -0.0011 & -0.0010 & & \\
\hline & $(3.15)^{*}$ & $(-2.24)^{*}$ & $(-0.42)$ & $(-0.60)$ & & \\
\hline \multirow[t]{2}{*}{ Model 4} & 1.3797 & -0.5201 & -0.0019 & & & \\
\hline & $(3.15)^{*}$ & $(-2.32)^{*}$ & $(-0.77)$ & & & \\
\hline \multirow[t]{2}{*}{ Model 5} & 1.2972 & -0.4255 & & & & \\
\hline & $(2.97)^{*}$ & $(-2.02)^{*}$ & & & & \\
\hline \multirow[t]{2}{*}{ Model 6} & 1.3288 & -0.5083 & & & & -4.630 \\
\hline & $(3.25)^{*}$ & $(-2.31)^{*}$ & & & & $(-1.82)$ \\
\hline
\end{tabular}

Table 1. Results of Fama-French regression for various factor combinations

Notes: $t$-statistics are given in parenthesis. ${ }^{*}$ indicates significance at $5 \%$ level.

Basher et al. (2007) also find significantly negative risk-return relationship in the DSE. Glosten et al. (1993) describe a situation where investors may not want higher return for taking higher risk. According to them, investors may not want higher risk premium if they find that they are better off bearing risk at time of particular volatility. Additionally, if future is risky the investors may like to invest now even if risk premium is low. Finally, for the general investors, investment in risk-free assets is not so easy in a frontier market such as Bangladesh. Such phenomenon may increase the price of risky assets (that is, lower expected return), ultimately reducing risk premium. The relation between market and stock return is significantly negative in model 5 as well as in other models, which suggests that this relation persists even in the presence of other variables.

Third, P/E ratio, dividend yield, and size do not have any impact on returns. Fourth, SMB, like market return has significantly negative relationship with returns, which also goes against the positive risk-return relationship suggested by finance theory. When market is more risky, risk-averse investors should become more interested in large firms and avoid small firms, resulting in higher price for large firms' stocks and lower price for small firms' stocks. This phenomenon suggests for higher (lower) required return for small (big) firms and larger spread between small and big firms' returns. As mentioned in the last paragraphed, such negative relationship between risk factors and returns is not very new in finance literature on Bangladesh stock market.

Table 2 presents regression results for small, medium, and large size firms. Constants are significantly positive. 
Cross-sectional returns still have negative relation with market returns. However, only large firms have significant risk-return relationship. In fact if the argument of Glosten et al. (1993) discussed above is true, then the risk-return relation for large firms should be more strongly negative because investors will switch away from small to large firms when future is uncertain.

Table 2. Results of Fama-French regression for different size firms

\begin{tabular}{lllllll}
\hline Firms & Constant & $\lambda_{m}$ & $\lambda_{p e}$ & $\lambda_{d y}$ & $\lambda_{m v}$ & $\lambda_{s m b}$ \\
\hline \multirow{2}{*}{ Large } & 2.838 & -1.3377 & -0.0652 & -0.0029 & -0.0038 & -0.5028 \\
& $(4.40)^{*}$ & $(-3.36)^{*}$ & $(-1.55)$ & $(-0.20)$ & $(-1.34)$ & $(-1.07)$ \\
\multirow{2}{*}{ Med } & 1.2548 & -0.4152 & -0.0172 & -0.0017 & 0.0000 & 0.4525 \\
& $(2.81)^{*}$ & $(-1.35)$ & $(-1.47)$ & $(-0.17)$ & $(0.04)$ & $(1.23)$ \\
\multirow{2}{*}{ Small } & 0.8560 & -0.7101 & -0.0136 & 0.0150 & -0.0021 & -0.2532 \\
& $(2.25)^{*}$ & $(-1.78)$ & $(-2.23)^{*}$ & $(1.32)$ & $(-1.88)$ & $(-0.81)$ \\
\hline
\end{tabular}

Notes: $t$-statistics are given in parenthesis. ${ }^{*}$ indicates significance at $5 \%$ level.

Table 3 gives the results of the full model for three size firms for two sub-periods - from 02/2000 through 03/2004 and from 04/2004 through 02/2008. Results are somewhat similar to previous two tables. For the earlier period, returns of all the size firms - large, medium and small - are explained by market returns. Effects of other factors are not evident. For the later period, market returns do not explain any of the size firms' returns. As before, other factors have limited capability of explaining the cross-section of expected returns. Thus, it seems that in the later period firms are not correlated to the market performances, which raises serious doubts on the manipulation-free trading activities of the market.

Table 3. Results of Fama-French regression for different size firms and two sub-periods

\begin{tabular}{|c|c|c|c|c|c|c|}
\hline Firm & Constant & $\lambda_{m}$ & $\lambda_{p e}$ & $\lambda_{d y}$ & $\lambda_{m v}$ & $\lambda_{s m b}$ \\
\hline \multicolumn{7}{|c|}{ Panel A: Period 02/2000 through 03/2004 } \\
\hline \multirow[t]{2}{*}{ Large } & 3.1762 & -1.4611 & -0.0116 & -0.0046 & -0.0014 & 0.2895 \\
\hline & $(4.94)^{*}$ & $(-3.10)^{*}$ & $(-0.76)^{*}$ & $(-0.50)$ & $(-0.92)$ & $(0.67)$ \\
\hline \multirow[t]{2}{*}{ Med } & 1.5975 & -0.8409 & -0.0069 & 0.0006 & 0.0001 & 0.1275 \\
\hline & $(3.59)^{*}$ & $(-2.23)^{*}$ & $(-0.69)$ & $(0.06)$ & $(0.23)$ & $(0.44)$ \\
\hline \multirow[t]{2}{*}{ Small } & 0.3878 & -0.9031 & -0.0044 & 0.0030 & -0.0010 & -0.5764 \\
\hline & $(0.86)$ & $(-2.31)^{*}$ & $(-0.78)$ & $(0.22)$ & $(-1.14)$ & $(-1.82)$ \\
\hline \multicolumn{7}{|c|}{ Panel B: Period 04/2004 through 02/2008 } \\
\hline \multirow[t]{2}{*}{ Large } & 2.2628 & -0.8551 & -0.2228 & 0.0018 & 0.0023 & 1.9858 \\
\hline & $(2.12)^{*}$ & $(-1.24)$ & $(-1.54)$ & $(0.05)$ & $(-0.11)$ & $(-2.11)^{*}$ \\
\hline \multirow[t]{2}{*}{ Med } & 1.6041 & -0.2018 & -0.2355 & 0.2682 & -0.0209 & -0.8582 \\
\hline & $(1.83)$ & $(-0.43)$ & $(-2.46)^{*}$ & $(2.41)^{*}$ & $(-2.46)^{*}$ & $(-0.93)$ \\
\hline \multirow[t]{2}{*}{ Small } & 1.0881 & -0.3293 & -0.0155 & 0.0493 & -0.0008 & 0.0009 \\
\hline & $(2.08)^{*}$ & $(-0.41)$ & $(-1.19)$ & $(-0.42)$ & $(-0.30)$ & $(-0.15)$ \\
\hline
\end{tabular}

Notes: $t$-statistics are given in parenthesis. ${ }^{*}$ indicates significance at $5 \%$ level. Data from $02 / 1998$ through $01 / 2000$ are lost due to the estimation of beta based on each firm's last 24 months' data.

It is believed that trade is a way of revealing information. Thus, the highly liquid firms have more opportunity to reflect information in their stock prices. Table 4 shows the results of regression where firms are sorted based on illiquidity. Results of this table is not that much qualitatively different from previous tables. The risk-return relationship is mostly insignificant for medium and low illiquid firms. However, highly illiquid firms show some evidence of significantly negative risk-return relationship. For highly illiquid firms, in four out of six regression models we have found significantly negative relationship between market return and stock return. Thus, this result is a very puzzling evidence of effect of liquidity on stock prices. This also indicates that stock trading does not play any role in disseminating information. 
Table 4. Results of Fama-French regression using various factor models for illiquidity-sorted firms

\begin{tabular}{|c|c|c|c|c|c|c|}
\hline Models & Constant & $\lambda_{m}$ & $\lambda_{p e}$ & $\lambda_{d y}$ & $\lambda_{m v}$ & $\lambda_{s m b}$ \\
\hline \multicolumn{7}{|c|}{ Panel A: High illiquid firms } \\
\hline Model 1 & $\begin{array}{c}0.6051 \\
(1.26)\end{array}$ & $\begin{array}{l}-0.7167 \\
(-2.96)^{*}\end{array}$ & $\begin{array}{c}-0.0002 \\
(-0.49)\end{array}$ & $\begin{array}{c}-0.0013 \\
(-0.13)\end{array}$ & $\begin{array}{c}-0.0001 \\
(-0.16)\end{array}$ & $\begin{array}{c}-0.2457 \\
(-1.24)\end{array}$ \\
\hline Model 2 & $\begin{array}{l}0.4665 \\
(0.95)\end{array}$ & $\begin{array}{l}-0.5938 \\
(-2.29)^{*}\end{array}$ & $\begin{array}{c}-0.0031 \\
(-0.64)\end{array}$ & $\begin{array}{c}-0.0076 \\
(-0.81)\end{array}$ & $\begin{array}{l}0.0003 \\
(0.34)\end{array}$ & \\
\hline Model 3 & $\begin{array}{l}0.3600 \\
(0.73)\end{array}$ & $\begin{array}{l}-0.4840 \\
(-1.96)^{*}\end{array}$ & $\begin{array}{l}-0.0066 \\
(-1.96)^{*}\end{array}$ & $\begin{array}{c}-0.0055 \\
(-0.80)\end{array}$ & & \\
\hline Model 4 & $\begin{array}{l}0.2844 \\
(0.56)\end{array}$ & $\begin{array}{c}-0.3963 \\
(-1.63)\end{array}$ & $\begin{array}{c}-0.0033 \\
(-0.98)\end{array}$ & & & \\
\hline Model 5 & $\begin{array}{l}0.2594 \\
(0.51)\end{array}$ & $\begin{array}{c}-0.3756 \\
(-1.56)\end{array}$ & & & & \\
\hline Model 6 & $\begin{array}{l}0.4455 \\
(0.90)\end{array}$ & $\begin{array}{l}-0.5405 \\
(-2.32)^{*}\end{array}$ & & & & $\begin{array}{c}-0.2462 \\
(-1.55)\end{array}$ \\
\hline \multicolumn{7}{|c|}{ Panel B: Medium illiquid firms } \\
\hline Model 1 & $\begin{array}{l}1.4868 \\
(3.10)^{*}\end{array}$ & $\begin{array}{c}-0.3984 \\
(-1.39)\end{array}$ & $\begin{array}{c}-0.0063 \\
(-0.39)\end{array}$ & $\begin{array}{c}-0.0055 \\
(-0.46)\end{array}$ & $\begin{array}{l}0.0006 \\
(-0.39)\end{array}$ & $\begin{array}{r}-0.4107 \\
(-1.14)\end{array}$ \\
\hline Model 2 & $\begin{array}{l}1.5554 \\
(3.10)^{*}\end{array}$ & $\begin{array}{c}-0.3282 \\
(-1.23)\end{array}$ & $\begin{array}{c}-0.0113 \\
(-0.76)\end{array}$ & $\begin{array}{l}-0.0027 \\
(-0.23)\end{array}$ & $\begin{array}{l}0.0002 \\
(-0.13)\end{array}$ & \\
\hline Model 3 & $\begin{array}{l}1.6466 \\
(3.35)^{*}\end{array}$ & $\begin{array}{c}-0.4200 \\
(-1.63)\end{array}$ & $\begin{array}{c}-0.0074 \\
(-0.68)\end{array}$ & $\begin{array}{c}-0.0054 \\
(-0.14)\end{array}$ & & \\
\hline Model 4 & $\begin{array}{l}1.6827 \\
(3.33)^{*}\end{array}$ & $\begin{array}{c}-0.3861 \\
(-1.57)\end{array}$ & $\begin{array}{l}0.0008 \\
(-0.11)\end{array}$ & & & \\
\hline Model 5 & $\begin{array}{l}1.6678 \\
(3.25)^{*}\end{array}$ & $\begin{array}{c}-0.3966 \\
(-1.66)\end{array}$ & & & & \\
\hline Model 6 & $\begin{array}{l}1.6256 \\
(3.32)^{*}\end{array}$ & $\begin{array}{c}-0.4852 \\
(-1.80)\end{array}$ & & & & $\begin{array}{r}-0.3287 \\
(-1.11)\end{array}$ \\
\hline \multicolumn{7}{|c|}{ Panel C: Low illiquid firms } \\
\hline Model 1 & $\begin{array}{l}1.8177 \\
(3.94)^{*}\end{array}$ & $\begin{array}{c}-0.4030 \\
(-1.22)\end{array}$ & $\begin{array}{c}-0.0254 \\
(-1.59)\end{array}$ & $\begin{array}{l}0.0035 \\
(0.34)\end{array}$ & $\begin{array}{c}-0.0016 \\
(-1.04)\end{array}$ & $\begin{array}{c}0.0673 \\
(0.24)\end{array}$ \\
\hline Model 2 & $\begin{array}{l}1.6281 \\
(3.24)^{*}\end{array}$ & $\begin{array}{l}-0.2666 \\
(-0.95)\end{array}$ & $\begin{array}{l}-0.0219 \\
(-1.33)\end{array}$ & $\begin{array}{l}0.0029 \\
(0.27)\end{array}$ & $\begin{array}{c}-0.0012 \\
(-0.72)\end{array}$ & \\
\hline Model 3 & $\begin{array}{l}1.6221 \\
(3.18)^{*}\end{array}$ & $\begin{array}{c}-0.2595 \\
(-0.95)\end{array}$ & $\begin{array}{c}-0.0093 \\
(-1.50)\end{array}$ & $\begin{array}{l}0.0025 \\
(0.39)\end{array}$ & & \\
\hline Model 4 & $\begin{array}{l}1.6918 \\
(3.28)^{*}\end{array}$ & $\begin{array}{c}-0.3447 \\
(-1.39)\end{array}$ & $\begin{array}{c}-0.0009 \\
(-0.15)\end{array}$ & & & \\
\hline Model 5 & $\begin{array}{l}1.5951 \\
(3.04)^{*}\end{array}$ & $\begin{array}{c}-0.2236 \\
(-1.04)\end{array}$ & & & & \\
\hline Model 6 & $\begin{array}{l}1.6974 \\
(3.50)^{*} \\
\end{array}$ & $\begin{array}{c}-0.3282 \\
(-1.20) \\
\end{array}$ & & & & $\begin{array}{c}0.0779 \\
(0.71) \\
\end{array}$ \\
\hline
\end{tabular}

Notes: $t$-statistics are given in parenthesis. ${ }^{*}$ indicates significance at $5 \%$ level.

Table 5 presents the results of multifactor regression models using firms sorted for illiquidity and two time periods - from 02/2000 through 03/2004 and from 04/2004 through 02/2008. Only market returns explain returns of low and medium illiquidity firms during the prior period. Other factors barely explain returns of firms. Thus, liquidity does not play any role to change the power of factors to explain the cross-section of stock returns.

Table 5. Results of Fama-French regression for two sub-periods (illiquidity-sorted firms)

\begin{tabular}{llccccc}
\hline Firm (Period) & Constant & $\lambda_{m}$ & $\lambda_{p e}$ & $\lambda_{d y}$ & $\lambda_{m v}$ & $\lambda_{s m b}$ \\
\hline High (02/00-03/04) & -0.5045 & -0.1044 & -0.0006 & -0.0050 & -0.0001 & -0.2263 \\
& $(-0.66)$ & $(-0.65)$ & $(-0.27)$ & $(-1.36)$ & $(-0.40)$ & $(-1.45)$ \\
High (04/04-02/08) & 1.8036 & -0.0073 & -0.0011 & -0.0075 & 0.0006 & 0.0624 \\
& $(1.61)$ & $(-0.04)$ & $(-0.38)$ & $(-0.94)$ & $(1.12)$ & $(0.22)$ \\
Medium (02/00-03/04) & 0.9413 & -0.8361 & 0.0022 & -0.0059 & 0.0006 & 0.3177 \\
& $(1.69)$ & $(-2.39)^{*}$ & $(0.12)$ & $(-1.02)$ & $(0.67)$ & $(1.01)$ \\
Medium (04/04-02/08) & 2.1763 & -0.4361 & -0.0223 & 0.0082 & -0.0008 & -0.7123 \\
& $(2.31)^{*}$ & $(-1.20)$ & $(-1.58)$ & $(1.06)$ & $(-0.63)$ & $(-1.43)$ \\
Low (02/00-03/04) & 0.9630 & -1.0225 & 0.0025 & -0.0066 & 0.0005 & 0.1164 \\
& $(1.49)$ & $(-2.12)^{*}$ & $(0.32)$ & $(-1.01)$ & $(0.06)$ & $(0.25)$ \\
Low (04/04-02/08) & 1.9418 & -0.1502 & -0.0104 & -.0019 & -0.0019 & 0.2239 \\
& $(2.45)^{*}$ & $(-0.37)$ & $(-2.04)^{*}$ & $(-0.45)$ & $(-2.72)^{*}$ & $(0.85)$ \\
\hline
\end{tabular}

Notes: $t$-statistics are given in parenthesis below the parameter values. ${ }^{*}$ indicates significance at $5 \%$ level. Based on illiquidity, firms are sorted into three categories - high, medium, and low. 


\section{Conclusion}

This paper investigates the factors that may influence the cross-section of stock returns in the DSE. We have used various combinations of factors such as dividend yield, size, price earnings ratio, spread between small and large firms, market return, lagged values of factors, illiquidity of stocks, and cross-sectional volatility of the market. However, results show that these factors hardly explain the cross-section of stock returns. Only market returns weakly explain stock returns. Interestingly, the relationship between market returns and stock returns has been consistently found to be negative, which contradicts the established notion of positive risk-return relationship. Using ARCH models, Basher et al. (2007) also find significantly negative risk-return relationship in the DSE. Glosten et al. (1993) describe a situation when investors may not want higher return for taking higher risk. They argue that investors may not want higher risk premium if they find that they are better off bearing risk at the time of particular volatility. Thus, as far as the DSE is concerned, there are two possible reasons for the negative relationship between risk and return. First, investors do not care about the logical risk-return relationship. Second, investors are too sensitive about future uncertainty, which makes them invest now even if risk is irrationally high for a particular level of return. Overall results do not suggest any strong relationship between cross-section of expected returns and well-known risk factors. There are at least two possible reasons. First, investors may not consider market risk factors in pricing stocks. Due to high participation of uninformed individual investors and lack of financial analysts/advisers, market may behave illogically. Second, investors may consider some unknown risk factor in pricing stocks. More research may be able to find those factors.

\section{References}

Ali, M. B. (2011). Impact of Micro and Macroeconomic Variables on Emerging Stock Market Return: A Case on Dhaka Stock Exchange (DSE). Interdisciplinary Journal of Research in Business, 1, 8-16.

Amihud, Y. (2002). Illiquidity and Stock Returns: Cross-section and Time-series Effects. Journal of Financial Markets, 5, 31-56. http://dx.doi.org/10.1016/S1386-4181(01)00024-6

Amihud, Y., \& Mendelson, H. (1986). Asset pricing and the bid-ask spread. Journal of Financial Economics, 17, 223-249. http://dx.doi.org/10.1016/0304-405X(86)90065-6

Avramov, D., \& Chordia, T. (2006). Asset Pricing Models and Financial Market Anomalies. Review of Financial Studies, 19, 1001-40. http://dx.doi.org/10.1093/rfs/hhj025

Banz, R. (1981). The Relationship between Return and Market Value of Common Stock. Journal of Financial Economics, 9, 3-18. http://dx.doi.org/10.1016/0304-405X(81)90018-0

Basher, S. A., Hassan, M. K., \& Islam, A. M. (2007). Time-varying Volatility and Equity Returns in Bangladesh Stock Market. Applied Financial Economics, 17, 1393-1407. http://dx.doi.org/10.1080/09603100600771034

Breen, W., Glosten, L. R., \& Jagannathan, R. (1989). Economic Significance of Predictable Variations in Stock Index Returns. Journal of Finance, 44, 1177-1189. http://dx.doi.org/10.1111/j.1540-6261.1989.tb02649.x

Brennan, M. J., \& Subrahmanyam, A. (1996). Market Microstructure and Asset Pricing: On the Compensation for Illiquidity in Stock Returns. Journal of Financial Economics, 41, 441-464. http://dx.doi.org/10.1016/0304-405X(95)00870-K

Brennan, M., Chordia, T., \& Subrahmanyam, A. (1998). Alternative Factor Specifications, Security Characteristics, and the Cross-section of Expected Stock Returns. Journal of Financial Economics, 49, 345-73. http://dx.doi.org/10.1016/S0304-405X(98)00028-2

Brown, P., Kleidon, A. W., \& Marsh, T. A. (1983). New Evidence on the Nature of Size-related Anomalies in Stock Prices. Journal of Financial Economics, 12, 33-56. http://dx.doi.org/10.1016/0304-405X(83)90026-0

Cakici, N., Fabozzi, F. J., \& Tan, S. (2012). Size, Value, and Momentum in Emerging Market Stock Returns. Working Paper, Fordham University.

Chordia, T., Subrahmanyam, A., \& Anshuman, R. (2001). Trading Activity and Expected Stock Returns. Journal of Financial Economics, 59, 3-32. http://dx.doi.org/10.1016/S0304-405X(00)00080-5

Chordia, T., Subrahmanyam, A., \& Roll, R. (2000). Market Liquidity and Trading Activity. Eleventh Annual Utah Winter Conference. http://dx.doi.org/10.2139/ssrn.237674

Chordia, T., Subrahmanyam, A., \& Tong, Q. (2012). Trends in the Cross-sectionof Expected Stock Returns. http://dx.doi.org/10.2139/ssrn.2029057.

Chowdhury, S. S. H., Rahman, M. A., \& Akhter, S. (2003). The Cross-section of Expected Returns: The Case of Dhaka Stock Exchange (DSE). South Asian Journal of Management, 10(2), 7-12. 
Chowdhury, S. S. H., Sadique, M. S., \& Rahman, M. A. (2001). Capital Market Seasonality: A Case of Dhaka Stock Exchange (DSE) Returns. South Asian Journal of Management, 8(3\&4), 1-7.

Daniel, K., Hirshleifer, D., \& Subrahmanyam, A. (1998). Investor Psychology and Security Market Under- and Over-reactions. Journal of Finance, 53, 1839-1885. http://dx.doi.org/10.1111/0022-1082.00077

Dey, M. K. (2005). Turnover and Return in Global Stock Markets. Emerging Markets Review, 6, 45-67. http://dx.doi.org/10.1016/j.ememar.2004.09.003

Easly, D., Hvidkjaer, S., \& O’Hara, M. (1999). Is Information Risk A Determinant of Asset Returns? Working Paper, Cornell University.

Eleswarapu, V. R. (1997). Cost of Transacting and Expected Returns in the NASDAQ Market. Journal of Finance, 52, 2113-2127. http://dx.doi.org/10.1111/j.1540-6261.1997.tb02754.x

Fama, E. F., \& French, K. R. (1992a). The Cross-Section of Expected Stock Returns. Journal of Finance, 47, 427-465. http://dx.doi.org/10.1111/j.1540-6261.1992.tb04398.x

Fama, E. F., \& French, K. R. (1992b). The Economic Fundamentals of Size and Book-to-market Equity. Working Paper, Graduate School of Business, University of Chicago, Chicago, IL.

Fama, E. F., \& French, K. R. (1993). Common Risk Factors in the Returns on Stocks and Bonds. Journal of Financial Economics, 33, 3-56. http://dx.doi.org/10.1016/0304-405X(93)90023-5

Fama, E. F., \& French, K. R. (2008). Dissecting Anomalies. Journal of Finance, 63, 1653-1678. http://dx.doi.org/10.1111/j.1540-6261.2008.01371.x

Fama, E. F., \& MacBeth, J. (1973). Risk, Return, and Equilibrium: Empirical Tests. Journal of Political Economy, 81, 607- 636. http://dx.doi.org/10.1086/260061

Fama, E. F., \& Schewrt, G. W. (1977). Asset Returns and Inflation. Journal of Financial Economics, 48, 115-146. http://dx.doi.org/10.1016/0304-405X(77)90014-9

Fang, L., \& Peress, J. (2009). Media Coverage and the Cross-section of Stock Returns. Journal of Finance, 64, 2023-2052. http://dx.doi.org/10.1111/j.1540-6261.2009.01493.x

Fraser, P., Hamelink, F., Hoesli, M., \& MacGregor, B. (2004). Time-varying Beta and the Cross-sectional Return-risk Relation: Evidence from the U.K. European Journal of Finance, 10, 255-276. http://dx.doi.org/10.1080/13518470110053407

Glosten, L., Jagannathan, R., \& Runkle, D. E. (1993). On the Relation between the Expected Value and the Volatility of the Nominal Excess Return on Stock. Journal of Finance, 48, 1779-1801. http://dx.doi.org/10.1111/j.1540-6261.1993.tb05128.x

Grinblatt, M., \& Han, B. (2005). Prospect Theory, Mental Accounting, and Momentum. Journal of Financial Economics, 78, 311-339. http://dx.doi.org/10.1016/j.jfineco.2004.10.006

Groenwold, N., \& Fraser, P. (1997). Share Prices and Macroeconomic Factors. Journal of Business Finance and Accounting, 24, 1367-1383. http://dx.doi.org/10.1111/1468-5957.t01-1-00168

Hou, K., \& Robinson, D. (2006). Industry Concentration and Average Stock Returns. Journal of Finance, 61, 1927-56. http://dx.doi.org/10.1111/j.1540-6261.2006.00893.x

Islam, M. M., Bhuyan, R., \& Rahman, M. Z. (2006). Size and Market-to-Book Value Ratio in Generating Equity Returns in the Emerging Stock Market of Bangladesh. Review of Business Research, 6(5), 18-22.

Jegadeesh, N., \& Titman, S. (1993). Returns to Buying Winners and Selling Losers: Implications for Stock Market Efficiency. Journal of Finance, 48, 65-92. http://dx.doi.org/10.1111/j.1540-6261.1993.tb04702.x

Lakonishok, J., \& Shapiro, A. C. (1984). Stock Returns, Beta, Variance and Size: An Empirical Analysis. Financial Analysts Journal, 40, 36-41. http://dx.doi.org/10.2469/faj.v40.n4.36

Lintner, J. (1965). Security Prices, Risk and Maximal Gains from Diversification. Journal of Finance, 20, 587-616. http://dx.doi.org/10.2307/2977249

Litzenberger, R., \& Ramaswamy, K. (1979). Dividends, Short-selling Restrictions, Tax-induced Investor Clienteles and Market Equilibrium. Journal of Financial Economics, 7, 163-196. http://dx.doi.org/10.1111/j.1540-6261.1980.tb02178.x

Liu, W. (2006). A Liquidity-augmented Capital Asset Pricing Model. Journal of Financial Economics, 82, 631-671. http://dx.doi.org/10.1016/j.jfineco.2005.10.001 
Lo, A. W., \& MacKinlay, A. C. (1990). When are Contrarian Profits Due to Stock Market Overreaction? Review of Financial Studies, 3, 175-205. http://dx.doi.org/10.1093/rfs/3.2.175

Merton, R. C. (1973). An Intertemporal Capital Asset Pricing Model. Econometrica, 41, 867-887. http://dx.doi.org/10.2307/1913811

Mobarek, A., \& Mollah, A. S. (2005). The General Determinants of Share Returns: An Empirical Investigation on the Dhaka Stock Exchange. Review of Pacific Basin Financial Markets and Policies, 8(4), 593-612. http://dx.doi.org/10.1142/S0219091505000518

Mossin, J. (1966). Equilibrium in a Capital Asset Market. Econometrica, 34(4), 768-783. http://dx.doi.org/10.2307/1910098

Obeidat, M. I. (2009). The Internal Financial Determinants of Common Stock Market Price: Evidence from Abu Dhabi Securities Market. Journal of Economic and Administrative Sciences, 25(1), 21-46. http://dx.doi.org/10.1108/10264116200900002

Pastor, L., \& Stambaugh, R. (2003). Liquidity Risk and Expected Stock Returns. Journal of Political Economy, 113, 642-685. http://dx.doi.org/10.1086/374184

Reinganum, M. R. (1981). Misspecification of Capital Asset Pricing: Empirical Anomalies Based on Earnings Yields and Market Values. Journal of Financial Economics, 9, 19-46. http://dx.doi.org/10.1016/0304-405X(81)90019-2

Rouwenhorst, K. G. (1999). Local Return Factors and Turnover in Emerging Stock Markets. Journal of Finance, 54, 1439-1464. http://dx.doi.org/10.1111/0022-1082.00151

Sadique, M. S., \& Chowdhury, S. S. H. (2001). Linear Causal Relationship between Changes in Stock Prices and Trading Volume: The Case of the DSE. Rajshahi University Studies, Part-C, 9, 13-25.

Sadique, M. S., \& Chowdhury, S. S. H. (2002). Serial Dependence in the Dhaka Stock Exchange Returns: An Empirical Study. Journal of Bangladesh Studies, 4(1), 47-57.

Sang-Gyung, J., Marathe, A., \& Shawky, H. A. (2003). Liquidity and Stock Markets in Emerging Equity Markets. Emerging Markets Review, 4, 1-24. http://dx.doi.org/10.1016/S1566-0141(02)00060-2

Sharpe, W. (1964). Capital Asset Prices: A Theory of Market Equilibrium under Conditions of Risk. Journal of Finance, 19, 425-442. http://dx.doi.org/10.1111/j.1540-6261.1964.tb02865.x

Uddin, M. H., Mohiuddin, M., Hossain, M. Z., \& Alam, M. J. (2007). Liquidity Risk in Dhaka Stock Exchange: An Empirical Study. AIUB Journal of Business and Economics, 6(2), 23-31.

Zhang, X. (2006). Information Uncertainty and Analyst Forecast Behavior. Journal of Finance, 61, 105-36. http://dx.doi.org/10.1111/j.1540-6261.2006.00831.x

\section{Notes}

Note 1 . We have also used momentum as one of the factors. We have defined momentum as the sum of past 60 days' returns of a stock. However, initial regression does not show any improvements in the model performance, consequently we have dropped momentum from further consideration.

Note 2. Monthly market illiquidity series are also created from the firm level illiquidity data and used as one of the factors in the regression. Although not reported, we have found insignificant relationship between market illiquidity and cross-section of stock returns. 